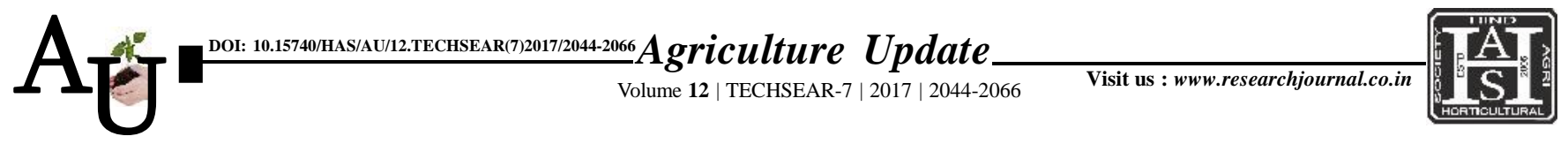

\title{
Research Article: Impacts of different sources of organic manures on soil physico-chemical properties, nutrient balance and yield of rice-greengram cropping sequence under organic farming
}

\author{
- SANKARAMOORTHY ALAGAPPAN, R. VENKITASWAMY AND G. \\ MARIAPPAN
}

Article Chronicle:

Received :

19.07.2017;

Accepted :

03.08.2017

KeY Words:

Soil physico-chemical

properties, Soil

available NPK,

Uptake of NPK by

crops, Nutrient

balance, Organic

farming, Grain, Straw

yield of rice-

greengram cropping

sequence

Author for correspondence :

SANKARAMOORTHY

ALAGAPPAN

Department Agronomy,

Tamil Nadu Agricultural

University, COIMBATORE

(T.N.) INDIA

Email : alga.s@

rediffmail.com

See end of the article for

authors' affiliations
SUMMARY : Field experiments were carried out at Tamil Nadu Agricultural University, Coimbatore, India during Samba (August-December) and Summer (February- May) seasons of 2012-2013 and 20132014. To study the soil physico-chemical properties, nutrient balance and yield in lowland rice-greengram cropping sequence under organic farming. The test variety of rice $\mathrm{CO}(\mathrm{R}) 48$ and the greengram variety (Co 6) were used in the two year cropping sequence under site-specific organic farming condition in comparison with RDF and INM. The field experiment consisted of fourteen treatments which were laid out in Randomized Block Design, replicated thrice and square planting $(25 \times 25 \mathrm{~cm})$ was adopted, the same layout was maintained for residual rice fallow summer greengram in both the years of study. The soil physical properties like bulk density, particle density, per cent pore space and water holding capacity. Similarly, the soil chemical properties like soil $\mathrm{pH}$, electrical conductivity (EC) and soil organic carbon (OC) content was also recorded after harvest of rice and after the harvest of greengram in the entire cropping sequence. The grain and straw yield of rice and greengram were recorded. Organic carbon content of soil was significantly increased with $100 \%$ RDN through green manure and it was followed by all the other organic treatments. The INM practice and recommended NPK fertilizers were noticed with lesser organic carbon content and the absolute control recorded with the lowest soil organic carbon content in both the years of study. The soil nutrient contents like soil available NPK, uptake of NPK by the crop and the nutrient balance (NPK balance) in the rice-greengam cropping sequence were also recorded. The less bulk density and more per cent pore space and water holding capacity values were recorded in all the organic treatments and the INM imposed treatment recorded at par values of the 100\% RDN through green manure treatment and the higher bulk density and lesser per cent pore space and water holding capacity was recorded with RDF treatment. The soil available NPK and uptake of NPK at harvest of rice, was higher recorded with INM practice followed by RDF treatment, whereas among the organic treatments, $100 \%$ RDN through green manure followed, by $25 \%$ RDN through each organic manures combination recorded more soil available and uptake of major nutrients in both the years of experimentation. Similar trend was noticed in grain and straw yield of rice and greengram during both the years of study. The $\mathrm{N}$ and $\mathrm{P}$ balance at the end of the cropping system was positive in all the treatments except the absolute control, whereas the negative $\mathrm{K}$ balance was noticed in the entire cropping system. 